\title{
WINNIPEG CHILD AND FAMILY SERVICES V. D.F.G.: Juridical Interference With Pregnant Women IN THE AllEged INTEREST OF THE FETUS
}

\author{
Sanda Rodgers ${ }^{*}$
}

In the last decade, a number of actions have arisen in which Canadian courts have suggested that pregnant women should be subjected to legal coercion where their behaviour allegedly placed the fetus at risk. These cases have taken the form of prebirth intervention and post-birth apprehension. Concern regarding these cases resulted in this issue specifically being made part of the mandate of the Royal Commission on New Reproductive Technologies. The Commission was to inquire into and report on "judicial interventions during gestation and birth"'. It did so, recommending against such intervention. ${ }^{2}$ Despite this recommendation, in Winnipeg Child and Family Services v. D.F.G. ${ }^{3}$ an action was brought to impose detention and treatment on a pregnant substance abusing woman in the absence of her consent. This case was heard on appeal by the Supreme Court of Canada. Reasons for judgment were issued in October, 1997.

Each of the earlier cases involved an application which purportedly was to ensure a healthy outcome to the pregnancy or to protect the child from alleged abuse after birth. ${ }^{4}$ In each of the cases the court's attention is turned to the fetus. For the most part, the woman, her choices, and the conditions in which those choices are made, disappear from judicial view.

A number of the cases involve post-birth apprehension under child welfare legislation. In Re Children's Aid Society for the District of Kenora and J.L., ${ }^{5}$ J.M. v. Superintendent of Family and Child Services ${ }^{6}$ and Ackerman v. McGoldrick, ${ }^{7}$ wardship proceedings were brought to remove a child from the custody of the mother after birth. In J.L. the infant apparently suffered from fetal alcohol syndrome resulting from the mother's alcohol addiction prior to and during pregnancy. In McDonald the baby was born addicted to methadone, which Ms. McDonald had been advised by her doctor to

\section{Faculty of Law, University of Ottawa.}

Order in Council No. P.C. 1989-2150, reprinted in Royal Commission on New Reproductive Technologies: Proceed With Care: Final Report of the Royal Commission on New Reproductive Technologies, vol. 1 (Ottawa: Minister of Government Services Canada, 1993) at 3 (Chairperson: P. Baird).

Ibid. vol. 2 at 964-65.

[1997] 3 S.C.R. 925 [hereinafter D.F.G.].

For a complete discussion of these cases see: S. Rodgers, "Juridical Interference with Gestation and Birth" in Royal Commission on New Reproductive Technologies: Legal and Ethical Issues in New Reproductive Technologies: Pregnancy and Parenthood, vol 4. (Ottawa: Minister of Government Services, 1993) at 33-46 (Chairperson: P. Baird). Children's Aid Society of Kenora v. L.(J.) (1981), 134 D.L.R. (3d) 249 (Ont. Fam. Ct.) [hereinafter J.L.]. Services and McDonald) (1982), 135 D.L.R. (3d) 330 (B.C.S.C) [hereinafter McDonald]. [1990] B.C.J. No. 2932 (Prov. Ct.) [hereinafter Ackerman]. 
continue taking during pregnancy. In Ackerman the child's mother had experienced addiction since the age of 12 . On discovering that she was pregnant she "made an attempt, a quite sincere attempt, to turn her life around". ${ }^{8}$ She entered a series of drug programs starting in a detox centre and moving from there to a residential program. She also married her partner. The baby was born apparently healthy and was released to her mother's care. Subsequently, the baby was apprehended after the mother's husband absconded with her.

In the first case, J.L., the court found that fetal alcohol syndrome had been "wilfully inflicted" upon the baby by her mother "neglecting or refusing to obtain proper remedial care or treatment ... when it was recommended by a legally qualified practitioner." The court's obiter remarks were to the effect that a fetus was entitled to protection under the Child Welfare Act although that $A c t$ referred to a child as "a person actually or apparently under sixteen years of age"; construing the legislative text to apply to a child "en ventre sa mere."

In McDonald apprehension was refused originally as the baby had not yet been discharged to the custody of her mother. The court held that Ms. McDonald had not been given an opportunity to demonstrate her parenting skills. On appeal, the court nonetheless commented, in obiter, on the meaning of "in need of protection" and its applicability to the fetus. Proudfoot J. held that "it would be incredible to come to any other conclusion than that a drug-addicted baby is born abused. That abuse had occurred during the gestation period." The child, therefore, was a child in need of protection within the legislation. The baby was released in the custody of her mother under strict conditions of supervision and subject to the "sole discretion" of a Dr. Segal as to the level of support required to protect the child. Later the child was apprehended and an order of permanent custody was made. On appeal this order was upheld.

A second set of cases involve applications allegedly on behalf of the fetus during pregnancy, prior to birth. Here the level of interference and the allegation of maternal irresponsibility appear in even sharper relief. The behaviour of the pregnant woman is seen to place the fetus in jeopardy and state action on behalf of the fetus is organized to protect it from the pernicious actions of the woman who carries it. In the first of these cases, Re Children's Aid Society of City of Belleville, Hastings County and T et $a l .{ }^{9}$ reliance is again placed on statutory text, here both the Child and Family Services Act and the Mental Health Act. The Mental Health Act allows for detention and assessment where an individual acts in a manner that places either herself or "another person" at risk..$^{10}$ The fetus is, in the view of the court, a "child" and that "child" was "another person" in need of protection. In a second case, Re Baby R.," the application was to allow a forced Caesarian section, despite the refusal of the pregnant, labouring woman herself. The fetus was apprehended, during labour, under the provisions of the Family and Child Service Act. On appeal the apprehension order was set aside on the

Ibid. at 3.

Children's Aid Society of Belleville v. T.(L.)(No. 2) (1987), 59 O.R. (2d) 204 (Fam. Ct.). But see Tremblay v. Daigle (1989), 62 D.L.R. (4th) 634 [hereinafter Tremblay v. Daigle]. (1988), 53 D.L.R. (4th) 69. 
grounds that the language of the Act did not expand the definition of "child" to include an unborn child, nor "person" to include an unborn person. The court pointed in contrast to the language of the Family Relations Act in which "child" is defined to include "a child not yet born ... but subsequently born alive."

Similarly, in $\operatorname{Re} A$.(in utero) ${ }^{12}$ an application was made to take a fetus into custody and to order the pregnant woman, P.A., to receive prenatal care, provide the name of her doctor to the Children's Aid Society, arrange for a hospital delivery and so advise the Society and, should she fail to comply, to be detained in hospital until delivery and to undergo all necessary medical treatment. The court held that the provisions of the Child and Family Services Act contained no language which entitled the fetus to protection under the Act, nor did the doctrine of parens patriae provide a residual common law jurisdiction for such an order.

Two other initiatives should be mentioned. Earlier litigation concerned a 1984 Yukon Territory amendment to the Children's Act, which provided that a pregnant woman suspected of subjecting her fetus to risk from fetal alcohol syndrome or other congenital injury could be placed under a supervision order at the behest of the Director. ${ }^{13}$ The constitutionality of this provision was challenged in Joe v. Director of Family and Children's Services (Yukon) ${ }^{14}$ and the provision was held to violate section 7 of the Canadian Charter of Rights and Freedoms. As well, in one instance a carceral sentence was imposed upon a woman where one would not otherwise have been expected, because she was pregnant. Judge Hogg of the Ontario Provincial Court sentenced a young woman to 60 days in prison on a charge of communicating for the purposes of prostitution and of failing to appear. She had pled guilty to the charge. The sentence that was imposed was well outside that normally imposed in such matters, and Judge Hogg denied counsel's request that his client be allowed to serve her sentence on weekends. The young woman also had a four year old child at home and had primary responsibility for the care of the child.

In the summer of 1997 , the series of cases purporting to recognize pre-natal abuse of the fetus by the pregnant woman, or to impose treatment on a woman over her objections, culminated in Winnipeg v. D.F.G., which was heard on appeal in the Supreme Court of Canada. This case posed precisely the factual and the legal questions that the earlier cases had addressed, and at the lower court levels incorporated some of the errors of legal analysis that the earlier cases had evidenced.

Ms. G., a member of the aboriginal community, is the mother of three children, none of whom were living with her. She was addicted to glue sniffing, which may cause damage to the developing nervous system of the fetus. At first instance Schulman J. ordered that Ms. G., then five months pregnant, be detained in the custody of the Director of Child and Family Services at the Health Sciences Centre until the birth of the child. He also ordered her to undergo treatment prescribed by the Director. As had 
occurred in earlier cases, he relied on the language of the Mental Health Act, ${ }^{15}$ despite expert evidence that Ms. G. was competent and not suffering from any mental disorder, and on the court's inherent parens patriae jurisdiction, which he purported to exercise on behalf of the fetus. The Manitoba Court of Appeal struck down the detention order, finding that there was no evidence of incompetency under the Mental Health Act. The Court of Appeal held that the trial judge had wrongly relied on the court's parens patriae jurisdiction, which provided protection only after birth.

Pursuant to the original order, Ms. G. had been confined to the Health Sciences Centre without her consent for the sole purpose of protecting her fetus. While the order was stayed two days later, and set aside on appeal by the Court of Appeal, Ms. G. voluntarily remained at the Health Sciences Centre until discharged in mid-August. In December Ms. G. gave birth to a healthy baby who remained in her custody. Social services provided her with twenty-four hour home support care.

Earlier, Ms. G. had voluntarily sought treatment for her addiction but had been turned away due to lack of space. Subsequently, and before the order was issued, she had agreed to take treatment. She was intoxicated when the agency worker arrived to escort her to the treatment centre. Rather than return later to escort Ms. G. to voluntary treatment, the Agency applied to have a mandatory detention order issued.

McLachlin J., writing for the majority, ${ }^{16}$ held that neither tort liability nor the doctrine of parens patriae could support an order of involuntary detention and treatment. Furthermore, although the appellant took the position that the order for mandatory treatment could be separated from the order for mandatory detention and was asking only for the later, McLachlin J. recognized that the issue of the detention order could not be separated from the issue of a mandatory treatment order. ${ }^{17}$

McLachlin J.'s reasons for judgment take as their starting premise that no legislation existed to provide authority for the detention order, but that it was open to the legislature to implement legislation if it chooses to do so. Such legislation, she points out, would be subject to Charter scrutiny.$^{18}$ Referring to the decision of the Court in Tremblay v. Daigle, McLachlin J. confirmed that the fetus has no legal rights until born, and that therefore the agency was purporting to act on behalf of no legal person in obtaining the detention order. ${ }^{19}$ In the absence of a basis for an action in tort, no

is R.S.M. 1987, c. M-110.

16 Lamer, La Forest, L'Heureux-Dubé, Gonthier, Cory and lacobucci JJ. concurring; Major J. wrote the dissent with Sopinka J. concurring.

$17 \quad$ D.F.G., supra note 3 at 937.

I8 "If Parliament or the legislatures wish to legislate legal rights for unborn children or other protective measures, that is open to them, subject to any limitations imposed by the Constitution of Canada" (ibid.). See also T. Brettel Dawson, "First Person Familiar: Legal Intervention in Pregnancy, Again" (forthcoming). 
injunction could be sought. Similarly, McLachlin J. refused to find that the parens patriae power of the Court could support an order on behalf of a fetus. ${ }^{20}$

McLachlin J. considered whether the Court should extend common law tort principles or the doctrine of parens patriae to recognize a right to protection on behalf of the fetus. She reviewed the breadth of changes that such judicial activism would imply. In her view, extending the law of tort to encompass rights in the fetus would require overturning the rule that rights accrue only at birth, recognizing a fetal right to sue the pregnant woman, recognizing a cause of action for lifestyle choices which may adversely affect others, and recognizing an injunctive remedy that would interfere with liberty and allow for involuntary confinement. In her view, judicial activism should be confined to incremental change, not major revisions with complex ramifications. ${ }^{21}$ Major revisions are best left to the legislature.

The proposed changes to the law of tort are major, affecting the rights and remedies available in many other areas of tort law. They involve moral choices and would create conflicts between fundamental interests and rights. They would have an immediate and drastic impact on the lives of women as well as men who might find themselves incarcerated and treated against their will for conduct alleged to harm others. And, they possess complex ramifications impossible for this Court to fully assess, giving rise to the danger that the proposed order might impede the goal of healthy infants more than it would promote it. In short, these are not the sort of changes which common law courts can or should make.

These are the sort of changes which should be left to the legislature. ${ }^{22}$

The basis of McLachlin J.'s reasons lies in her determination that no legislative text nor existing common law principle provides the protection to the fetus that the Appellant alleged. The determination that there is no common law entitlement to protection follows from the decisions of the Court in both Morgentaler ${ }^{23}$ and in Tremblay v. Daigle. ${ }^{24}$ The suggestion that the legislature could specifically enact fetal protection legislation suggests that the common law position in tort and the principles of parens patriae could be revised by legislation, although McLachlin J. reminds us that any such legislation would be subject to Charter scrutiny. ${ }^{25}$ For this reason, the

Ibid. at 955. "The law as it stands is clear: the courts do not have parens patriae or wardship jurisdiction over unborn children."

"As a general rule, judicial change is confined to incremental change "based largely on the mechanism of extending an existing principle to new circumstances'; courts will not extend the common law "where revision is major and its ramifications complex"' (D.F.G., supra note 3 at 940, relying on Watkins v. Olafson, [1989] 2 S.C.R. 750 at 760-61).

D.F.G., ibid. at 941 .

[1988] I S.C.R. 30 [hereinafter Morgentaler].

Supra note 10.

In 1984 the Yukon Children's Act, R.S.Y. 1986, c. 22, was amended to include s. 133:

Where the director has reasonable and probable grounds to believe and does believe that a foetus is being subjected to a serious risk of suffering from foetal alcohol syndrome or other congenital injury attributable to the pregnant woman subjecting herself during pregnancy to addictive or intoxicating substances, the director may apply to a judge for an order requiring the woman to participate in such reasonable supervision or counselling as the order specifies in respect of her use of addictive or intoxicating substances. 
judgment may be considered a narrow application of traditional principles of judicial reticence and statutory interpretation. There is no Charter analysis, nor are equalitybased arguments specifically included in the analysis. However, unlike the lower court decisions in D.F.G. and in the earlier cases, the context in which Ms. G. lives, and the lives of women subject to state interference with reproductive autonomy are significantly more present in McLachlin J.'s analysis.

McLachlin J. notes that to allow orders of the kind requested would "have an immediate and drastic impact on the lives of women as well as men who might find themselves incarcerated and treated against their will for conduct alleged to harm others." ${ }^{26}$ She notes that the fetus and the pregnant woman are one entity in fact as well as in law:

To permit an unborn child to sue its pregnant mother-to-be would introduce a radically new conception into the law; the unborn child and its mother as separate juristic persons in a mutually separable and antagonistic relation. Such a legal conception, moreover, is belied by the reality of the physical situation; for practical purposes, the unborn child and its mother-to-be are bonded in a union separable only by birth. ${ }^{27}$

She specifically recognizes that there is little precedent for imposing liability based on lifestyle choices, pointing out that if such liability were to attach it potentially would attach to persons other than pregnant women.

Are children to be permitted to sue their parents for second-hand smoke inhaled around the family dinner table? Could any cohabitant bring such an action? Are children to be permitted to sue their parents for spanking causing psychological trauma or poor grades due to alcoholism or a parent's undue fondness for the office or the golf course? ${ }^{28}$

She reinforces her recognition of the implications of such an order for a pregnant woman by noting that "[t]he difficulties multiply when the lifestyle in question is that of a pregnant woman whose liberty is intimately and inescapably bound to her unborn child."29

Furthermore, her understanding of the degree of interference and the impact that such an order would have on the lives and autonomy of all women underlies her judgment. Her attention to the impact on women's lives is apparent in her discussion of the Appellant's suggestion that such orders can be appropriately constrained by limiting the duty of care to an obligation to:

The provision was found unconstitutional in Joe v. Director of Family and Children Services (1986), 1 Y.R. 169 (S.C.).

D.F.G., supra note 3 at 941 . However, her reference to the impact on men is suggestive of the degree to which her reasons eschew an equality based analysis. Her point that the Appellant's position may impact on others than the pregnant woman re-occurs throughout her reasons for judgment. 
[R]efrain from activities that have no substantial value to a pregnant women's well-being or right of self-determination and that have the potential to cause grave and irreparable harm to the child's life, health and ability to function after birth. ${ }^{30}$

McLachlin J. asks:

What does substantial value to a woman's well-being mean? What does a woman's well-being include? What is involved in a woman's right of self-determination - all her choices or merely some of them? And if some only, what is the criterion of distinction? ... No bright lines emerge to distinguish tortious behaviour from non-tortious once the door is opened to suing a pregnant mother for lifestyle choices adversely affecting the fetus. ${ }^{31}$

McLachlin J. also recognizes that medical prediction of damaging behaviour varies over time and that to impose legal liability on pregnant women would make them responsible for correctly identifying and complying with medical practices that are subject to constant change. ${ }^{32}$ In this context, McLachlin J. recognizes that particular communities of women are more likely to be subjected to injunctions and damage claims:

The pregnant women most likely to be affected by such a "knowledge" requirement would be those in lower socio-economic groups. Minority women, illiterate women, and women of limited education will be the most likely to fall afoul of the law and the new duty it imposes and to suffer the consequences of injunctive relief and potential damage awards. ${ }^{33}$

McLachlin J. also emphasized the fact that issues of alcohol addiction, substance abuse and poor nutrition are not matters of choice. ${ }^{34}$ For this reason, she recognizes that imposing a duty of the kind the Appellant favoured would not necessarily result in deterrence of harmful behaviour nor in positive pregnancy outcomes. ${ }^{35}$ Similarly, in rejecting the extension of the doctrine of parens patriae to the fetus McLachlin $J$. notes that any such order would "interfere with the pregnant woman's ability to choose where to live and what medical treatment to undergo." 36 In her view it would "seriously intrude on the rights of women." 37

In contrast, the dissent written by Major J. (Sopinka J. concurring), argues that the common law parens patriae jurisdiction should be expanded to allow for detention in the interest of fetal health. A number of assumptions underlie the reasons and the

\footnotetext{
30 $\quad$ lbid. at 949.

31 Ibid.

32 "The difference between confinement and freedom, between damages and non-liability, may depend on a grasp of the latest research and its implications" (ibid. at 950).

3

34

Ibid.

Ibid.; see also 952: "It is far from clear that the proposed tort duty will decrease the incidence of substance-injured children. Indeed, the evidence suggests that such a duty might have negative effects on the health of infants."

Ibid. at 959.

lbid.
} 
choice of facts. ${ }^{38}$ Among the facts which Major J. identifies as crucial are notions of the choices afforded to Ms. G. including: a decision to continue the pregnancy and not to have an abortion, to continue glue sniffing and to reject treatment for her addiction (although he notes that Ms. G. had agreed to enter a residential treatment program), a reliance on technology to identify empirically and accurately the health of the fetus in utero $^{39}$ and the efficacy of in utero treatment of the fetus. ${ }^{40} \mathrm{Ms}$. G's addiction to solvents is described in the language of "lifestyle choice." 41 He reviews the history of her addiction and the loss of her earlier children to child welfare services. He notes not only that Ms. G. was provided with twenty-four hour care after the birth of her child but that after her discharge from treatment, and prior to the birth, Ms. G. was provided with regular visits from a teaching homemaker and a public health nurse who provided advice on parenting skills and encouragement to her to remain drug free. Among the additional facts of which he takes note are several reports on the impact of fetal alcohol syndrome and the impact of addiction on the fetus. (However, he fails to note that the reports on which he relies do not recommend mandatory intervention).

Major J. argues that the parens patriae jurisdiction of the courts should be expanded to allow the protection of the fetus. He describes the "born alive" rule as evidentiary only and not substantive and argues that it has been overtaken by modern science. While he recognizes the interference with women's autonomy that his proposal implies, he argues that state interference can be avoided by choosing abortion. ${ }^{42} \mathrm{He}$ fails to consider that a pregnant woman may continue her pregnancy not as a result of deliberate choice but because of lack of access to therapeutic abortion, or cultural, social, personal or family constraints. ${ }^{43}$

This insistence on the availability of abortion turns previously understood notions of choice on their head and is deeply disturbing. Where women previously struggled to establish a constitutionally-protected entitlement to abortion where her own understanding of her particular situation so required, access to abortion and choice here become an encouraged and court-sanctioned mechanism for avoiding state-imposed detention or intervention.

Major J. takes the view that intervention would be allowable only where the woman has decided to carry the pregnancy to term, where there is proof on a balance of probabilities that the abusive activity will cause serious and irreparable harm to the

On the importance of the facts chosen see: M.J. Mossman, "Feminism and Legal Method: The Difference it Makes" in M. Albertson Fineman \& N. Sweet Thomadsen, eds., At the Boundaries of Law: Feminism and Legal Theory (New York: Routledge, 1991) at 283.

"Present medical technology renders the "born alive" rule outdated and indefensible. We no longer need to cling to an evidentiary presumption to the contrary when technologies like real time ultrasound, fetal heart monitors and fetoscoppy can clearly show us that a foetus is alive and has been or will be injured by conduct of another" (D.F.G., supra note 3 at 981 ). Jbid. at $961,962$.

Ibid.

Ibid. at 972.

N. Bowes, V. Burstyn \& A. Knight, Access Granted: Too Often Denied (Ottawa: Canadian Abortion Rights Action League, 1998); D.E. Roberts, "Punishing Drug Addicts Who Have Babies: Women of Color, Equality, and the Right of Privacy" (1991) 104 Harv. L. Rev. 1419. 
fetus, where the remedy is the least intrusive option, and where the process is procedurally fair. ${ }^{44}$

Major J. does not comment further on his choice of a civil standard rather than a higher standard of proof for what is potentially a more invasive and draconian interference with constitutionally-protected inviolability and autonomy than that contemplated by criminal law. Nor does he consider that detention or imposed intervention can hardly be described as the "least intrusive option" where assistance and support are available alternatives and are the solution recommended by professionals working with women with addiction and similar difficulties. ${ }^{45} \mathrm{He}$ does not refer to the difficulty in making an accurate medical prediction as to the health of the fetus or the impact of intervention. ${ }^{46}$

In this context an ambiguous example chosen by Major J. illustrates the point. Major $\mathrm{J}$. speculates as to the appropriateness of state interference to prevent a woman from taking thalidomide for morning sickness. ${ }^{47}$ It seems that the example is designed to demonstrate that highly risky behaviour of little benefit must be arrested, given the direct relationship between the drug and fetal limb anomalies. However, the high level of disabilities at birth resulted from the prescription of thalidomide to control morning sickness by the medical profession itself. Major J.'s example highlights the difficulty of relying on medical prediction, rather than the compelling necessity for state interference.

Finally, cases involving interference with a woman's autonomy on behalf of the fetus during pregnancy are notorious for their failure to ensure that procedural fairness is present. Instead hearings are attenuated, take place while the pregnant woman is in labour, in the absence of legal representation, without careful proof of medical facts and cross examination, and disproportionately impact on poor women, women of colour, aboriginal women and women who are already the subject of state scrutiny. In this case, the Statement of Claim and Notice of Motion were filed on July 30, returnable August 1. Affidavit medical evidence was filed on July 29 and 31 . The motion was heard August 3. Viva voce evidence and oral argument were heard. A psychiatric assessment was ordered and filed with the court August 6 and the motions judge pronounced an interim order. Written reasons were released on August 13. Ms. G's request for a two

D.F.G., supra note 3 at 973.

M. Jackman, "The Constitution and the Regulation of New Reproductive Technologies" in Overview of Legal Issues in New Reproductive Technologies, vol. 3 (Ottawa: Supply and Services Canada, 1994) 1; and M. Jackman, "The Charter as a Barrier to Unwanted Medical Treatment of Pregnant Women in the Interests of the Foetus" (1993) 14 Health L. Can. 49.

ACOG Committee Opinion Number 55, Patient Choice: Maternal-Fetal Conflict (October 1987). "Medical knowledge and judgement have limitations and fallibility, which the obstetrician must recognize when assigning clinical risks and benefits in order to advise patients. Methods for detecting fetal distress or deterioration are not always reliable indicators of poor outcome..." D.F.G., supra note 3 at 987. 
week adjournment was denied. There was virtually no cross-examination by counsel for Ms. G. and no evidence was called on her behalf. ${ }^{48}$

Major J. comments that the limited intervention of detention without treatment serves the interest of both the mother [sic] and the fetus and prevents unnecessary spending by the Canadian government to care for children born with disabilities. ${ }^{49}$ This reference to an economic justification for state intervention in the lives of pregnant women is the subject of no further comment in the decision, nor, it is submitted, is it a legitimate basis on which to curtail protected rights of autonomy and inviolability. The reference is, however, not entirely surprising. The clear undercurrent of much of the public rhetoric on coerced treatment of pregnant women revolves around notions of appropriate and inappropriate public expenditure. Such concerns are exacerbated where the communities which are seen as generating the expense to the state and the taxpayers are those who are marginalised, impoverished and perceived as nonproductive units. ${ }^{50}$ This understanding underlies the ease with which abortion to terminate such pregnancies is seen as appropriately available and as a state-sanctioned option.

Major J. also suggests that a tort action may be possible by the child against her mother for "lifestyle choices," where the necessary elements of a negligence claim can be proven. ${ }^{51}$ Major J.'s reasons are based on an argument that the doctrine of parens patriae should be expanded to allow for court action on behalf of the fetus. He does not consider the relationship of such an expanded doctrine to Charter protected rights, although common law principles are subject to Charter compliance. ${ }^{52}$

Neither the majority nor the minority in D.F.G. assess state interference in the reproductive lives of women in a manner fully compatible with women's equality and participation in Canadian life. Nor do they place this incidence of juridical intervention within a history of legal involvement with women's reproductive capacity, of which this is only the most recent example. ${ }^{53}$ Despite some limited recognition of the disproportionate impact on particular communities of women in the reasons of the majority, the decision of the Court fails to incorporate a full understanding of the degree to which state interference would be imposed in a discriminatory fashion. Aboriginal women in Canada have been subjected to historical and continuing inequality, which inequality has attached to their reproductive capacity in particularly

Factum of the Intervener Women's Health Clinic Inc., Metis Women of Manitoba Inc., Manitoba Association of Rights and Liberties at 5.

D.F.G., supra note 3 at 993.

sin

J. Aubry, "Aboriginal baby boom spells crisis, study says" The Ottawa Citizen (11 May 1998) A5. D.F.G., supra note 3 at 988, relying on Dobson (Litigation Guardian of) v. Dobson (1997), 148 D.L.R. (4th) 332 (N.B.C.A.), on appeal to the Supreme Court of Canada.
RWDSU v. Dolphin Delivery Ltd., [1986] 2 S.C.R. 573, 33 D.L.R. (4th) 174.

For a broader discussion of these issues see Rodgers, supra note 4 and "State Intervention in the Lives of Pregnant Women" in T. Caulfield \& J. Downie, eds., Introduction to Health Care, Butterworths (forthcoming 1999). 
pernicious ways. ${ }^{54}$ Aboriginal families and aboriginal women have persistently been seen by the State as unable to care for their children. Aboriginal families have been overrepresented in state sponsored initiatives to remove children from their families and their communities, including to residential schools and to adoption out of the community. ${ }^{55}$ In the seven reported cases that involve state intervention described here four involve women from the aboriginal community. All involve women who have a history of involvement with social services. State-imposed treatment impacts disproportionately on low-income and minority women and women already under scrutiny by social service agencies. ${ }^{56}$

Nor does the Court clearly consider that State interference would be imposed disproportionately on women and not on men. The suggestion that women should be subjected to surveillance and control of their pregnancies arguably would extend to include the whole of women's reproductive lives, from adolescence to menopause. This would impose a unique set of obligations upon women not imposed on men. It would preclude women from undertaking activities that are legal for others on the basis of biological difference. This would constitute discrimination on the basis of pregnancy, which previously has been recognized by the Court as impermissible sex-based discrimination. ${ }^{57}$ No comment is made by the Court on the fact that others owe no such obligation to family members, although an obligation by one person toward another, such as father to son or brother to brother, would not require the level of personal sacrifice of autonomy and inviolability that the suggested regime would impose on pregnant women. ${ }^{58}$

Legally justified interference would require women to submit their behaviour to the supervision of the Canadian state and require the courts to act as enforcers of inequality, rather than as protectors of equality. The minority decision fails to consider

For a description of the procedures with regard to abortion provided by the Stanton Yellowknife Hospital in the Northwest Territories, which were insufficient with regard to pain control and counselling, and where over half of the patients were aboriginal, see Report of the Abortion Services Review Committee, Northwest Territories (June 1992).

P.A. Monture, "A Vicious Circle: Child Welfare and the First Nations" (1989) 3 C.J.W.L. 1; A.C. Hamilton \& C.M. Sinclair, Report of the Aboriginal Justice Inquiry of Manitoba (Winnipeg: Province of Manitoba, 1991) at 477, 479, 520; M. Kline, "Complicating the Ideology of Motherhood: Child Welfare Law and First Nation Women" (1993) 18 Queen's L.J. 306; Racine v. Woods, [1983] 2 S.C.R. 173; Rodgers, supra note 4; A. McGillivray, "Therapies of Freedom: The Colonization of Aboriginal Childhood" in A. McGillivray, ed., Governing Childhood (Dartmouth Press: Aldershoot, 1996) 13; Royal Commission on Aboriginal Peoples, People to People, Nation to Nation: Highlights From the Report of the Royal Commission on Aboriginal Peoples (Ottawa: Minister of Supply and Services Canada, 1996).

Rodgers, supra note 4; I.J. Chasnoff, H.J. Landress \& M.E. Barrett, "The Prevalence of Illicit Drug or Alcohol Use During Pregnancy and Discrepancies in Mandatory Reporting in Pinellas County, Florida" (1990) 322 New Eng. J. Med. 1202; V.E.B. Kolder, "Court-Ordered Obstetrical Interventions" (1987) 316 New Eng. J. Med. 1192; Roberts, supra note 43 at 1491. is no legal basis on which to force a bone marrow donation between family members even where death will result. 
the conflict between the position taken and Charter protected rights to inviolability, ${ }^{59}$ or the Court's previous determination that the fetus is not entitled to legal recognition prior to birth. ${ }^{60}$ Instead, the minority position creates a sex-specific burden on Canadian women based on cultural stereotypes which entrench rather than address existing inequality. ${ }^{61}$

Furthermore, all evidence suggests that intervention of this kind is counterproductive. Such intervention focuses only on the health of the fetus, devaluing the woman and her needs except to the degree that she is reproducing. Nor is state intervention of the kind contemplated identified as effective either by women themselves ${ }^{62}$ or those who provide care and service to women.

The organized professional groups most closely linked to provision of services to pregnant women have policies against mandatory, state ordered intervention. The Ethics Committee of the Society of Obstetricians and Gynecologists of Canada (SOCG) issued a statement opposing involuntary medical intervention. Referring to its 1995 report Healthy Beginnings, the SOGC reaffirmed its position that physicians "...should encourage women engaged in substance abuse to seek treatment." ${ }^{63}$ The SOGC report recognizes that the threat of imposed intervention erodes the trust necessary to allow pregnant women to access prenatal care and other services necessary to their own health and the health of their fetus, and notes that pregnant women have been denied access to treatment in some cases because of their pregnancy. For these reasons the SOGC opposes involuntary intervention in the lives of pregnant women. Rather the SOGC insists that:

Morgentaler, supra note 23; Fleming v. Reid (1991), 82 D.L.R. (4th) 298 at 312 (Ont. C.A.); Rodriguez v. B.C. (A.G.), [1993] 3 S.C.R. 519 at $588-89$.

Tremblay v. Daigle, supra note 10; $R$. v. Sullivan, [1991] 1 S.C.R. 489 at 502-503.

Factum of the Intervener, Women's Legal Education and Action Fund, Winnipeg Child and Family Services at 12, para. 34; M. Jackman, "Constitutional Contact with the Disparities in the World: Poverty as a Prohibited Ground of Discrimination Under the Canadian Charter and Human Rights Law" (1994) 2 Rev. of Constit. Studies 76; P. Jos, et al., "The Charleston Policy on Cocaine Use During Pregnancy: A Cautionary Tale" (1995) 23 J. of Law, Medicine \& Ethics 120.

S.C. Boyd, "Women and Illicit Drug Use" (1994) 5 Int. J. Drug Policy 185.

SOGC Clinical Practice Guidelines Policy Statement No. 67, "Involuntary Medical Intervention in the Lives of Pregnant Women" (October 1997); Healthy Beginnings: Guidelines for Care During Pregnancy and Childbirth. No. 18, December 1995 [hereinafter Healthy Beginnings]; Royal College of Physicians and Surgeons of Canada. Biomedical Ethics Committee, "Reflections on the Physician's Responsibility to Mother and Fetus" (March, 1992); Royal College of Obstetricians and Gynecologists of Great Britain Guidelines - "A Consideration of the Law and Ethics in Relation to Court-authorized Obstetric Intervention" (1994) 1 Ethics at paras. 3.8.10, 4.5.1, 5.12, supplemented December 1996 ("It is inappropriate, and unlikely to be helpful or necessary, to invoke judicial intervention to overrule an informed and competent woman's refusal of a proposed medical treatment, even if her refusal might place her life and that of her fetus at risk"). See also E. Flagler, F. Baylis \& S. Rodgers, "Bioethics for clinicians: 12 Ethical dilemmas that arise in the care of pregnant women: Rethinking "maternal-fetal conflicts" (1997) 156:12 Can. Med. Assoc. J. 1729. 
[A]dequate resources be made available for the development of effective programs and services to ensurc that all pregnant women have access to good health care, proper counselling and rehabilitation, safe living conditions, and nutrition. ${ }^{\text {ct }}$

Similar positions have been issued by the Royal College of Physicians and Surgeons, the American College of Obstetricians and Gynecologists and by the American Medical Association. ${ }^{65}$

Concern about fetal welfare is problematic where only limited provision for prenatal care, for post-natal and infant care, and for the provision of housing and nutrition is made for children after their birth. In particular, First Nations women and infants have a health status that falls well below that of the general Canadian population. Their need is for basic reproductive health care, not for coercive measures. First Nations women live in housing conditions that are substandard in comparison with those of the general Canadian population, with a corresponding impact on maternal and infant health indicators. Average annual income is lower than that of the general population. There is a proven linkage between income levels and health status. Thus, pregnant First Nations women living both on and off reserve are at high risk. Their health care needs reflect different cultural expectations and needs. Reproductive health care services for First Nations women and their children must reflect a culturally appropriate response to a First Nations concept of health.

An additional concern is the degree to which the women subjected to state intervention appear to be living in relationships that are subject to violence. ${ }^{66}$ In several of the lower court judgments, reference is made to the violence of the male partner, but never in a way that considers the impact of violence on the women's ability to engage successfully with health care or social services or to care for her children. Nor is reference made to the responsibility of the male partner.

Issues of inadequate prenatal health care and the impact of addictions on maternal and fetal health are areas of serious concern. The recent literature on addictions

SOGC Ethics Committee, "Policy Statement: Involuntary Intervention in the Lives of Pregnant Women" (1997) 19 J. Soc. Obstet. Gynecol. Can. 1201 at 1203.

The Ethics Committee of American College of Obstetricians and Gynecologists issued a formal opinion with regard to alleged fetal maternal conflict and concluded that:

Obstetricians should refrain from performing procedures that are unwanted by a pregnant woman. The use of judicial authority to implement treatment regimens in order to protect the fetus violates the pregnant woman's autonomy. Furthermore, inappropriate reliance on judicial authority may lead to undesirable social consequences, such as the criminalization of noncompliance with medical recommendations.

The American Medical Association takes a similar view:

[A] pregnant woman and her fetus share a physical interdependency that a third-party tortfeasor and the fetus do not. The nature of the relationship between the pregnant woman and her fetus makes problematic tort liability against the mother for prenatal injuries. 
concludes that coercive measures are seriously inadequate and are counterproductive. ${ }^{67}$ Instead, a recent study by the Hospital for Sick Children in Toronto concluded that pregnant women who are drug users can avoid injury to their infants if they are able to stop using drugs in the first three months of the pregnancy. ${ }^{68}$ As well, post-natal environments are crucial. These challenges are best met not by incarceration and punitive measures but by economic and other support services provided in a meaningful manner. ${ }^{69}$

The appropriate response to pregnancy and childbirth is to offer easy access to culturally appropriate support services for women and children, designed to meet the broad needs of women and children. ${ }^{70}$ Not only are punitive or coercive measures counterproductive and a violation of women's legal rights, but they suggest a patriarchal response designed to reinforce gender and class roles, rather than a legitimate attempt to meet the broad needs of women and to foster the birth of healthy children.

Nonetheless, the outcome of Winnipeg Child and Family Services v. D.F.G. reaffirms women's reproductive autonomy and constitutional entitlement, although in language often both cautious and constrained and with an invitation to the legislature to consider intervening. Non-consensual intervention, whether by imposed treatment or detention has been rejected. The possibility that federal or provincial legislatures may embark upon a legislative response remains possible. Any such legal strategy likely would bear all the markers of inequality and violate Charter protections. It is unlikely that any such response would further the goals of healthy women and children and encourage women's full participation in the Canadian State.

The Board of Trustees of the American Medical Association recommends that "pregnant substance abusers should be provided with rehabilitative treatment appropriate to their specific physiological and psychological needs." Similar conclusions have been reached by others studying the problem of maternal drug use, among them the Center for the Future of Children, which, in a study dealing with drug-exposed infants, recommended the following:

A woman who uses illegal drugs during pregnancy should not be subject to special criminal prosecution on the basis of allegations that her illegal drug use harms the fetus. Nor should states adopt special civil commitment provisions for pregnant women who use drugs. See C. Maloney, "Cocaine and Pregnancy: Study shows users who quit drug have normal babies" Ottawa Citizen (10 August 1991) E12. See also L. Gostin, "Waging a War on Drug Abusers: an Alternative Public Health Vision" (1990) 18 Law, Medicine and Health Care 388; B. Zuckerman, "Drug-Exposed Infants: Understanding the Medical Risk" (1991) I Future of Children 34.

See C.B. McCullough, "The Child Welfare Response" (1991) 1 Future of Children 61 at 69 ("Child maltreatment is associated with alcohol and drug abuse, and also with poverty, family and community dysfunction, and homelessness. Child maltreatment is also associated with society's lack of commitment to prevention and early intervention services for families at risk of abusive behaviour. Hardest hit by the drug epidemic have been disadvantaged communities and families who were previously coping if only marginally").

70 "Prevention efforts should target women before and during their childbearing years, as well as those who influence such women, including their partners, families, and the community. All efforts should be: family-centred and culturally sensitive, to address the pregnant woman as well as her partner and family in the context of their community: and comprehensive, to draw on all services appropriate to the often complex social, economic and emotional needs of these women" ("Prevention of Fetal Alcohol Syndrome (FAS) and Fetal Alcohol Effects (FAE) in Canada", a joint statement with Health Canada and eighteen other signatories, Canadian Pediatric Society, 1996 (http://www.cps.ca/english/statements/FN/cps96-01.htm) [emphasis in original]). 